\title{
Families Without Schools: Rurality, Correspondence Education, and the Promise of Schooling in Interwar Western Canada
}

\section{Mona Gleason}

Using a collection of settler family letters to the Elementary Correspondence School (ECS) in British Columbia, the first provincial government-supported "schooling by mail" arrangement of its kind in Canada, I highlight the efforts of rural families to secure an education for their children in the period between the First and Second World Wars. The settler families who took advantage of correspondence schooling did so without the benefit of a professional teacher or a dedicated schoolhouse. This arrangement proved onerous for many settler families. In their letters to the ECS, adults and young people articulated the belief that the provincial government needed to do more to provide educational services for them. Families were acutely aware of their contributions to the prosperity of the province and, in return, they demanded schools for their children. Given the unique perspectives reflected through this collection of letters, my examination is situated in the interstices between rural schooling and correspondence schooling.

Elementary schooling in urban centers, particularly in the nineteenth and twentieth centuries, has long been a major focus of historical research in the United States, Canada, and internationally, resulting in a rich and deep body of scholarship. Over these crucial centuries, increasing numbers of students attended school in cities and towns, and it was here that much policymaking and social reform took place. ${ }^{1}$ Rural schooling has never been ignored, as I explore in the

Mona Gleason is a professor in the Department of Educational Studies at the University of British Columbia. She has published widely in the history of education and the history of children and youth in Canada. Her recent research focuses on the history of rural education in the western Canadian province of British Columbia. This research was supported by a grant from the Spencer Foundation.

${ }^{1}$ The historiography on urban schooling internationally is voluminous and it is impossible to capture the length and breadth of scholarship on urban schooling here. Some of the major works in the contexts of North America and Western Europe include David Tyack, The One Best System: A History of American Urban Education (Cambridge: Harvard University Press, 1974); D. Reeder, ed., Urban Education in the Nineteenth Century (London: Taylor and Francis, 1977); R. K. Goodenow and 
sections to follow, but histories dedicated to it have tended to key off themes driven primarily by urban concerns. Themes regarding the administration and management of material schools, enrollment trends, curricular and pedagogical trends, and the professionalization of teaching staff, among others, have tended to dominate the literature. Regardless of urban or rural context, the historiographical spotlight has shone most brightly on the setting of the traditional "brick-andmortar" or material school (stately and looming or small and neglected), staffed by teachers (professional or not) and attended by students (regularly or irregularly) from various families (influenced by class, gender, race, ethnicity, ability, and sexuality norms and expectations; and committed to, or indifferent or hostile to, compulsory schooling). The historiography devoted to distance, or correspondence, education in rural settings, while less extensive, supplements this preoccupation with traditional material schools as sites of learning. Notwithstanding some important exceptions that I will return to in the following sections, undereducated or underqualified adults, not elementary schoolchildren, however, tend to feature most prominently in histories of rural correspondence schooling.

In this article, I explore attitudes toward, and experiences of, correspondence schooling on the part of white settler elementary schoolage children and their families in the western Canadian province of British Columbia (BC) in the interwar period. ${ }^{2}$ I do so by analyzing

W. E. Marsden, eds., The City and Education in Four Nations (Cambridge, MA: Cambridge University Press, 1992); Anna Davin, Growing up Poor: Home, School and Street in London, 1870-1914 (London: Rivers Oram Press, 1996); and R. D. Gidney and Wynn Millar, How Schools Worked: Public Education in English Canada, 1900-1940 (Montréal: McGill-Queen's University Press, 2012).

${ }^{2}$ Note that in the context of Canada, as I explain in greater detail in the proceeding text, education is under the jurisdiction of provincial governments. The designation of "settler" is important in this paper since it was white families who were able to take advantage of the offer of correspondence schooling. After 1920, Aboriginal children, their families "managed" by the Canadian government, were mandated to attend school. See Brian Titley, A Narrow Vision: Duncan Campbell Scott and the Administration of Indian Affairs in Canada (Vancouver: University of British Columbia Press, 1986). While many historians have focused on the development of residential schools on the part of the Canadian government and a number of religious orders as a response to the "Indian problem," other historians have provided much needed attention to the experience of Aboriginal children in provincial day schools. See Eve Chapple, "A Curious Case of 'Integrating' the 'Integrated': Government Education Policy and the School at Telegraph Creek, British Columbia, 1906 to 1951" (master's thesis, University of Victoria, 2012). For important work on later attempts at integration, see Helen Raptis, "Implementing Integrated Education Policy for On-Reserve Aboriginal Children in British Columbia, 19511981," Historical Studies in Education/Revue d'histoire de l'éducation 20, no. 1 (Spring 2008), 118-46; Helen Raptis, "Exploring the Factors Prompting British Columbia's 
five hundred letters rural children and parents wrote to educational officials and teachers of the Elementary Correspondence School (ECS) between the early 1920s and the late 1930s, during the peak of ECS activity. ${ }^{3}$ The ECS, the first provincial government-supported "schooling by mail" arrangement of its kind in Canada, was established to offer free public school elementary curriculum to children. These children, typically part of the white, rural working class, either lived too far from a public school (more than five miles) or had limited access due to difficult physical terrain.

For all their potential as historical sources, it is important to acknowledge the limitations of the ECS letters. The most obvious is the contingent nature of letter writing and the meanings it reflects and conceals. Historians have argued that letters written in the past represent layers of meaning, not simply a single "truth," and are shaped by changing literary conventions. ${ }^{4}$ This applies to letters written by children as much as those written by adults. As is the case with most archival collections, and in letter writing specifically, there are many unknowns at play in the ECS family files. How did social decorum, or lack of it, shape what settler parents, children, and ECS officials wrote?

First Integration Initiative: The Case of Port Essington Indian Day School," History of Education Quarterly 51, no. 4 (Nov. 2011), 519-43; Helen Raptis, "Blurring the Boundaries of Policy and Legislation in the Schooling of Indigenous Children in British Columbia, 1901-1951," Historical Studies in Education/Revue d'bistoire de l'éducation 27, no. 2 (Fall 2015), 65-77; and Helen Raptis (with members of the Tsimshian Nation), What We Learned: Two Generations Reflect on Tsimshian Education and the Day Schools (Vancouver, BC: UBC Press, 2016).

${ }^{3}$ The Elementary Correspondence School operated between 1919 and 1969 under the auspices of the then named Department of Education in British Columbia. Elementary Correspondence School Collection, British Columbia Department of Education, British Columbia Archives, GR-0470 (hereafter BCA). On a history of the ECS that focuses primarily on the administrative relationship with the provincial Department of Education, see Tara Suzanne Toutant, "Equality by Mail: Correspondence Education in British Columbia, 1919 to 1969" (master's thesis, University of Victoria, 2004).

${ }^{4}$ On the complexities of letters as historical sources, see Caroline Bland and Máire Cross, eds., Gender and Politics in the Age of Letter Writing, 1750-2000 (Aldershot, UK: Ashgate, 2003); Rebecca Earle, "Introduction: Letters, Writers and the Historian," in Epistolary Selves: Letters and Letter Writers, 1600-1945 (Aldershot, UK: Ashgate, 1999); James S. How, Epistolary Spaces: English Letter-Writing from the Foundation of the Post Office to Richardson's Clarissa (Aldershot, UK: Ashgate, 2003); and Charlotte J. MacDonald, introduction to Women Writing Home, 1700-1920: Female Correspondence Across the British Empire, ed. Charlotte J. MacDonald (London: Pickering \& Chatto , 2006). On children and letter writing in the Canadian West, including insights into children's experiences in private academies and schools, or under private tutelage, see Kathryn Bridge "Being Young in the Country: Settler Children and Childhood in British Columbia and Alberta, 1860-1925," (PhD diss., University of Victoria, 2012), particularly 38-41, 61-76. 
What kinds of letters were lost, never sent, or excluded from files? And what criteria were used to determine what was kept for the archive and what was left out?

An additional limitation involves the matter of perspective and, more to the point, whose perspective is reflected in these letters. Voices reflecting circumstances outside the hegemonic settler point of view are not found in the ECS letters. Given the marginalization of Indigenous peoples in the history of $\mathrm{BC}$ and Canada, this is important to keep in mind. Since the federal government retained control over the education of Aboriginal peoples, they attended federally sponsored residential, and occasionally day, schools instead of regularly attending public schools. ${ }^{5}$ The history of the ECS is, as Nancy Beadie and her colleagues have argued, an example of how "imperial projects structured the political economy of education in the West." As I will argue, the need for labor in various natural resource extraction industries in the province pushed settlers further and further onto Aboriginal lands. ${ }^{6}$ I remain sensitive to this history of colonization and exclusion and acknowledge that the absence of Indigenous voices regarding rural schooling in the ECS letters speaks to the history of colonization and education that continues to unfold in Canada.

The families who took advantage of correspondence schooling through the ECS did so without the benefit of a professional teacher or a dedicated schoolhouse in their community. Instead, teaching and learning took place at home with parents, most particularly mothers, as surrogate teachers. Parents, some explicitly citing the promise of schooling to secure their children's future, wrote to the ECS administrators and teachers, established their inability to get their children to the nearest school, and registered them for lessons. In turn, they received lessons in the mail, had their children complete the work,

${ }^{5}$ Historical work on the history of residential schooling in Canada is extensive. Useful overviews in the context of British Columbia include Jean Barman, "Schooled for Inequality: The Education of British Columbia Aboriginal Children," in Children, Teachers and Schools: In the History of British Columbia, 2nd ed., ed. Jean Barman and Mona Gleason (Edmonton, AB: Brush Education, 2003), 55-80; Sarah De Leeuw, "If anything is to be done with the Indian, we must catch him very young': Colonial Constructions of Aboriginal Children and the Geographies of Indian Residential Schooling in British Columbia, Canada," Children's Geographies 7, no. 2 (May 2009), 123-40; and Erin Neegan, "Excuse Me: Who Are the First Peoples of Canada? A Historical Analysis of Aboriginal Education in Canada Then and Now," International Fournal of Inclusive Education 9, no. 1 (Jan. 2005), 3-15.

${ }^{6}$ Nancy Beadie, Joy Williamson-Lott, Michael Bowman, Teresa Frizell, Gonzalo Guzman, Jisoo Hyun, Joanna Johnson, Kathyrn Nicholas, Lani Phillips, Rebecca Wellington, and La'akea Yoshida, "Gateways to the West, Part 1: Education in Shaping the West," History of Education Quarterly 56, no. 3 (Aug. 2016), $424-47$. 
sent the lessons back to the ECS teachers for marking and feedback, and the cycle of lessons continued. The letters from ECS families form a significant portion of the archival collection of the ECS, but they have been to date largely overlooked by historians in Canada. This inattention belies their value: they amplify the voices of parents and children generally, and rural working-class settler mothers and children in particular, whose perspectives remain largely silent in histories of both rural and correspondence schooling. Barbara Pini and colleagues suggest that while much scholarship has been dedicated to "naming, critiquing and redressing how particular social locations shape experiences of inclusion and exclusion in education," the perspectives of "those who live outside the metropolitan mainstream" have been largely ignored. ${ }^{7}$ As Damien Collins and Tara Coleman argue in their review of social geographies of education, the school should not be seen simply as a place, bounded by geography, but rather as also baving a place in the imagination of a community. ${ }^{8}$ In letters written to the ECS, we read this articulation of school as having an important place in the imagination of settler families and the urgent and politicized response its material absence evoked. They call on the educational authorities associated with the ECS to recognize and reciprocate their contributions to the growth and prosperity of the province, marked by their hard and unending labor, with the appropriate provision of schooling for their children. Settlers communicate how they believed schooling should be experienced and how the state should support their needs in this regard.

Given the unique perspectives reflected through this collection of letters, my examination is situated in the interstices between rural schooling and correspondence schooling. My "historiographical hybridity" approach attempts to highlight contributions to both established historiographies while drawing attention to what is unique in this example of rural correspondence schooling. To this end, I employ the lens of location, in concert with attention to class, gender, and race, as a critical category of analysis. I argue that rurality, as a location both material and rhetorical, was marshaled by parents, and to some extent children, through the ECS letters in two related ways that aimed to help them secure what they needed, and indeed what they felt they

${ }^{7}$ Barbara Pini, Suzanne Carrington, and Lenore Adie, "Schooling Elsewhere: Rurality, Inclusion and Education," International Fournal of Inclusive Education (Oct. 2014), 1-8.

${ }^{8}$ Damien Collins and Tara Coleman, "School Geographies of Education: Looking Within, and Beyond, School Boundaries," Geography Compass 2, no. 1 (Jan. 2008), 283. 
deserved, to effectively get an education. ${ }^{9}$ First, parents leveraged their rural isolation and the difficult physical terrain that surrounded them in their letter writing as justification for their demands for provincial assistance. When this assistance fell short, as it often did, parents employed politicized rhetoric to chastise provincial officials for excluding their children from school based on their rural location. Rurality, they argued, characterized by the agricultural and resource extraction work that they undertook (particularly based on cattle ranching, forestry, fishing, and mining), entitled them to assistance and did not excuse governmental officials from their duty to educate rural children on par with others in the province. Letters written by children and youth to the ECS reveal the importance they placed on schooling as a way to mitigate loneliness and isolation, to keep up with peers, and to forge meaningful relationships with others, including their teachers. Some, like their parents, wrote to ask for more support for their schooling. Young people wrote seeking advice on immediate lessons but also on their plans for, and anxieties about, the future. In an era prior to the rise of the welfare state in Canada, and mired in the economic hardships of the Great Depression, ECS parents and children nevertheless identified and problematized the provincial government's inability or unwillingness to adequately provide and administer educational resources. Rurality, as a physical place of labor and in politicized rhetoric, was an important strategy ECS families employed to argue for a meaningful formal education for children.

\section{Contextualizing the ECS in International and Canadian Histories of Rural and Correspondence Schooling}

Neither a case of traditional rural schooling nor a case of traditional adult-focused correspondence schooling, the history of BC's ECS, as reflected in the family letters, contributes to both historiographies while forging a hybrid space in between. In the international historiography devoted to rural schooling, for example, many studies have focused on the relationship between the spread of mass schooling in the countryside and the character of, and relationship to, state formation. Scholars have shown how climbing enrollment rates in rural

\footnotetext{
${ }^{9}$ On the importance of paying attention to rural areas of Canada in histories of education in general, see the special issue of Historical Studies in Education/Revue d'histoire de l'éducation (Spring 2012). R. W. Sandwell, "Introduction to Special Issue on the History of Rural Education in Canada," Historical Studies in Education/Revue d'bistoire de l'éducation 24, no. 1 (Spring 2012), 43-46. Geographers, in particular, have used the concept of "rurality" as a conceptual framework in work such as Andy C. Pratt, "Discourse of Rurality: Loose Talk or Social Struggle?" Fournal of Rural Studies 12, no. 1 (Jan. 1996), 69-78.
} 
schools tended to correlate positively with significant state funding investments in public education. These investments, however, were not even or unproblematic, nor were they forthcoming in all contexts. The idiosyncrasies of local conditions in relation to mass schooling and state involvement have been shown to be key factors within these histories. In the case of the early history of Canada West (the designation of the province of Ontario prior to Canadian Confederation in 1867), Bruce Curtis has shown that resistance to the management of particular aspects of public schools accompanied increased state involvement. Schools built in hard-to-reach locations, those felt to be overly expensive to maintain, and those staffed by unpopular teachers were often decried, and occasionally destroyed, by angry ratepayers. ${ }^{10}$ Mary Jo Maynes has likewise drawn our attention to the interplay between schooling at the local level and state authority in the examples of France and Germany. Her analysis demonstrates that while state authority had an impact on how rural schooling evolved, including such pivotal interventions as compulsory school law, local traditions and existing practices were equally in play. State interventions were never solely responsible for how and why state schooling emerged. ${ }^{11}$ In her useful analysis of the example of the northern United States in the early republican era, Beadie likewise demonstrates that local conditions, particularly "corporate legal power and the distribution of wealth" in rural areas, had more positive impact on the development of mass schooling than did state intervention. ${ }^{12}$ The expansion of pre-Revolution Russian public education among the rural peasantry, as Ben Eklof argued in the mid-1980s, was never simply a matter of state intervention. It was desired by the ruling elite in order to diffuse the possibility of social unrest on the part of the uneducated, but it was only when peasant families saw real and measurable benefits accruing from elementary education that they took advantage of public schooling. ${ }^{13}$ When local rural populations could clearly see the potential for positive social reproduction through

${ }^{10}$ Bruce Curtis, "Patterns of Resistance to Public Education: England, Ireland, and Canada West, 1930-1890," Comparative Education Review 32, no. 3 (Aug. 1988), 318-33.

${ }^{11}$ Mary Jo Maynes, Schooling for the People: Comparative Local Studies of Schooling History in France and Germany, 1750-1850 (New York: Holmes \& Meier, 1985).

${ }^{12}$ Nancy Beadie, "Education, Social Capital and State Formation in Comparative Historical Perspective: Preliminary Investigations," Paedagogica Historica 46, no. 1-2 (Feb.-April 2010), 15-32.

${ }^{13}$ Ben Eklof, "Peasant Sloth Reconsidered: Strategies of Education and Learning in Rural Russia Before the Revolution," Fournal of Social History 14, no. 3 (Spring 1981), 355-85; see also Ben Eklof, Russian Peasant Schools: Officialdom, Village Culture, and Popular Pedagogy, 1861-1914 (Berkeley: University of California Press, 1986). 
schooling, as the international historiography suggests, state efforts to build public systems in rural areas tended to be successful. ${ }^{14}$

In the absence of significant capacity for local support, however, rural schools struggled to achieve and maintain acceptable educational standards. In the Canadian context, this was ironic given that the majority of the population was officially designated as "rural" until the 1970s. ${ }^{15}$ The serious lack of governmental attention to supporting rural schools in the early twentieth century was hardly limited to BC or indeed to Canada. Historians across Western Europe, North America, Sweden, and Finland, for example, have documented the struggles of rural people and teaching professionals to ensure adequately provisioned school buildings and high standards of instruction. ${ }^{16}$ Focused on the history of rural schooling in the Atlantic provinces of Canada, Michael Corbett has argued that governmental parsimony shaped, and continues to shape, the challenges associated with rural schooling. He has demonstrated that the "rural problem" in Canadian education, paralleling that highlighted in other international histories, grew from two key factors: (1) the content of schooling was found to be largely irrelevant and imposed from the outside on rural people, and (2) the need to balance homesteading labor and schooling weakened interest in, and attendance at, rural schools. ${ }^{17}$ In

${ }^{14}$ Chad Gaffield and Gérard Bouchard have written about the role of schooling and education, particularly in securing literacy, among rural families in Ontario and Quebec as part of broader strategies of social reproduction. See Chad Gaffield and Gérard Bouchard, "Literacy, Schooling and Family Reproduction in Rural Ontario and Quebec," Historical Studies in Education/Revue d'histoire de l'éducation 1, no. 2 (Fall 1989), 201-18. See also the early scholarship of Lewis Solomon on the role of "opportunity costs," particularly the foregone earnings or labor support of children in family decision-making regarding school attendance. Lewis C. Solomon, "Opportunity Costs and Models of Schooling in the Nineteenth Century," Southern Economic Fournal 37, no. 1 (July 1970), 66-83.

${ }^{15}$ R. W. Sandwell, "Notes toward a History of Rural Canada, 1870-1940," in Social Transformation in Rural Canada: Community, Cultures, and Collective Action, ed. John R. Parkins and Maureen G. Reed (Vancouver: UBC Press, 2013), 21-42.

${ }^{16}$ Tracy L. Steffes, "Solving the 'Rural School Problem': New State Aid, Standards, and the Supervision of Local Schools, 1900 to 1933," History of Education Quarterly 48, no. 2 (May 2008), 181-220. Johannes Westberg's research demonstrates that rural school building in the Swedish region of Sundsvall increased in cost over the nineteenth century, becoming a serious social and economic consideration in educational financing. Far from marginalized projects on shoestring budgets, rural schools in that context increasingly marked a burdensome investment for many Swedish communities. Johannes Westberg, "How Much Did a Swedish Schoolhouse Cost to Build? Rewriting the History of 19th-Century Rural Schoolhouses," Scandinavian Fournal of History 39, no. 4 (Sept. 2014), 448-71.

${ }^{17}$ Michael Corbett, "A Protracted Struggle: Rural Resistance and Normalization in Canadian Educational History," Historical Studies in Education/Revue d'bistoire de 
the American context, Tracy Steffes argues that the "rural problem" became, in fact, an important rallying cry for rural reform and a catalyst for increased state intervention. She argues that attention to the "rural problem" helped to stimulate and legitimate significant new state interventions into local schools and to define the forms of state aid, regulation, and bureaucracy in a formative period of state development."18

For their part, rural schoolteachers often struggled with community standards of morality, discretion, and commitment. Intrusions into teachers' private lives were not uncommon. ${ }^{19}$ In their study of the "problem" of rural schooling in BC in the 1920s, J. D. Wilson and Paul J. Stortz argue that while educational bureaucracies expanded in urban centers, rural schooling in remote districts around the province suffered. ${ }^{20}$ As they suggest, the differences between rural and urban schools, especially at the high school level, meant that by the 1920s many rural students were falling behind their urban counterparts. $^{21}$

l'éducation 13, no. 1 (Spring 2001), 19-48; and Michael Corbett, "We Have Never Been Urban: Modernization, Small Schools, and Resilient Rurality in Atlantic Canada," Fournal of Rural and Community Development 9, no. 3 (2014), 186-202. Other Canadian studies include Paul W. Bennett, Vanishing Schools, Threatened Communities: The Contested Schoolhouse in Maritime Canada, 1850-2010 (Halifax, NS: Fernwood Publishing, 2011); and Gidney and Millar, How Schools Worked. See also Eugen Weber, Peasants into Frenchmen: The Modernization of Rural France, 1870-1914 (Stanford: University of California Press, 1976); and Wayne E. Fuller, The Old Country School: The Story of Rural Education in the Middle West (Chicago: University of Chicago Press, 1982).

${ }^{18}$ Steffes, "Solving the "Rural School Problem," 181.

${ }^{19}$ For studies examining intrusions into teachers' lives, see Peter V. Meyers, "Professionalization and Social Change: Rural Teachers in Nineteenth Century France," Fournal of Social History 9, no. 4 (Summer 1976), 542-58; Richard J. Altenbaugh, "Oral History, American Teachers, and a Social History of Schooling: An Emerging Agenda," Cambridge Fournal of Education 27, no. 3 (Nov. 1997), 313-30; Mary Anne Poutanen, “Unless she gives better satisfaction': Teachers, Protestant Education, and Community in Rural Quebec, Lochaber and Gore District, 1863-1945," Historical Studies in Education/Revue d'bistoire de l'éducation 15, no. 2 (Fall 2003), 237-72; and Erkko Anttila and Ari Väänänen, "Rural Schoolteachers and the Pressures of Community Life: Local and Cosmopolitan Coping Strategies in Mid-Twentieth-Century Finland," History of Education 42, no. 2 (March 2013), 182-203.

${ }^{20}$ J. D. Wilson and Paul J. Stortz, "May the Lord have mercy on you': The Rural School Problem in British Columbia in the 1920s," BC Studies 79 (Autumn, 1988), 57-58.

${ }^{21}$ School Inspector Leslie Bruce reported in 1920, for example, that many rural and assisted schools remained "simply not satisfactory ... very badly planned ... hardly one has a library ... salaries too low to attract capable and experienced teachers ... students are far below that of pupils in other schools....," in F. Henry Johnson, A History of Public Education in British Columbia (Vancouver: Publications Centre, 
Broadly speaking, the historiography devoted to rural schooling has established how local conditions played key roles in shaping its character and its success (or failure) in comparison to urban contexts. The starting point for much of this scholarship is the presence of a physical school - often small and consisting of a single room-and a teacher, lay or professional. Histories of distance, or correspondence, schooling in rural districts start from a significantly different point: schooling took place outside the presence of a school, with or without the help of a dedicated teacher. Scholarship on the historical development of correspondence schooling in contexts such as Zimbabwe, Botswana, and Malawi have nonetheless recognized important connections between the establishment of correspondence schooling networks and the state's effort to foster a literate citizenry. The growth of correspondence schooling, particularly after the Second World War and aimed at either training new teachers for the countryside or engendering basic adult literacy skills, marked an important facet of "development," particularly in colonized African countries. ${ }^{22}$

In other contexts, such as Mexico, Russia, Sweden, New Zealand, and the United States, historians have produced studies that focus on a broad range of purposes associated with correspondence schooling beyond basic adult literacy. Vocational education aimed at increasing workers' skills, satisfying post-secondary degree requirements, helping soldiers to transition to civilian society, professional accreditation, and self-improvement were all pursued through correspondence education. In Mexico in the early 1920s, educational resources were sent to teachers and professors in communities across the country. These professionals would then offer courses of instruction to local residents. ${ }^{23}$ Correspondence education in Russia also has a long history, shifting from a focus on "workers' circles" in the early twentieth century to "vocational training" by the 1950s; correspondence schooling shifted again after the mid-twentieth century to cater almost

University of British Columbia, 1954), 97; see also Shirley Cuthbertson, A Highlight History of British Columbia Schools, Royal BC Museum, Online Exhibits, Thunderbird Park, Schoolhouse Display, March 25, 2008, 4, http://www.royalbcmuseum.bc.ca/ exhibits/tbird-park/html/present/stann/sb5/sb5hhist.pdf

${ }^{22}$ Munhuweyi Peresuh and Obert Paradzai Ndawi, "Education for All-The Challenges for a Developing Country: The Zimbabwe Experience," International Fournal of Inclusive Education 2, no. 3 (July 1998), 209-24; Bogadi Nage-Sibande, "The Development of Distance Education in Botswana," Quarterly Review of Distance Education 6, no. 3 (Fall 2005), 243-53; and Ross A. Perkins, Simeon M. Gwayi, Paxton A. Zozie, and Barbara B. Lockee, "Distance Education in Malawi," Educational Technology Research and Development 53, no. 4 (Dec. 2005), 101-108.

${ }^{23}$ Manuel Moreno Castañeda, "A History of Distance Education in Mexico," Quarterly Review of Distance Education 6, no. 3 (Fall 2005), 227-32. 
exclusively to post-secondary students too far from major state universities to take advantage of the lectures of prominent Russian professors. ${ }^{24}$ While histories of correspondence education in Sweden have established the importance of vocational training to school graduates hoping to enhance their trade skills, Anders Nilsson draws our attention to the important role such education played in the lives of older adults. As an overlooked form of adult education, Nilsson argues, correspondence education in Sweden laid the groundwork for state-operated adult education centers that arose later in the period. ${ }^{25}$ Chris Bricknell's revealing examination of correspondence schooling for servicemen and women in World War II New Zealand demonstrates the state's interest in helping soldiers leave the war behind after returning home. Bricknell argues that the army's correspondence education scheme aimed to "civilize" soldiers and prepare them for citizenship in postwar New Zealand. Such schemes betray the role of the state in employing various forms of education to the purpose of social engineering. ${ }^{26}$

In the context of the United States, Richard Hampel has argued that despite a rich history of correspondence schooling over the twentieth century, "historians have neglected this topic." ${ }^{27}$ Numerous companies, individuals, universities, colleges, and churches, Hampel points out, took advantage of mail services and new technology to offer instruction in everything from upgrading skills in white- and blue-collar trades to learning a new instrument and earning professional credentials. Hampel suggests that while correspondence education marked an important segment of American education over the century, a paucity of documentary evidence has hampered investigative work by historians. This would most certainly apply in the case of rural correspondence schooling. His analysis of the transcripts of the annual meetings of the National Home Study Council (NHSC)created by an association of proprietary correspondence schoolsfrom the late 1920s to the early 1940s reveals the NHSC's goal of protecting the quality of education its members sold and managed. ${ }^{28}$

\footnotetext{
${ }^{24}$ Marina Moiseeva, "Distance Education in Russia: Between the Past and the Future," Quarterly Review of Distance Education 6, no. 3 (Fall 2005), 217-25.

${ }^{25}$ Anders Nilsson, "The Unknown Story: Vocational Education for Adults in Sweden, 1918-1968," History of Education 43, no. 5 (Sept. 2014), 615-34.

${ }^{26}$ Chris Bricknell, "Soldier to Civilian: Army Education and Postwar New Zealand Citizenship," History of Education 39, no. 3 (May 2010), 363-82.

${ }^{27}$ Robert L. Hampel, "The National Home Study Council, 1926-1942," American Fournal of Distance Education 23, no. 1 (Feb. 2009), 4-19.

${ }^{28}$ Ibid., 6-8. See also the role that radio technology played in encouraging "schools of air" in the United States and Canada. Tina R. Lamb, "The Emergence of Educational Radio: Schools of Air," TechTrends 56, no. 2 (March 2012), 9-11;
} 
Hampel uncovers the constant concern regarding the reputation of the homeschool model on the part of the NHSC and the regulatory and licensing battles it fought to preserve members' place in the educational marketplace.

A major and enduring gap in both the history of rural schooling and correspondence schooling nevertheless remains the perspectives of students, particularly schoolchildren, and their families within these histories. The experience of adults, lay and professional, tends to dominate the manuscript evidence available to historians, common to both historiographies. Colin Symes provides a clearer glimpse into the perspectives of children and parents in his work on the spatial aspects of correspondence schooling in the context of Australia. Symes explores how spatial practices and technologies associated with schooling by distance, including exercise books, film, school radio, and magazines, enabled rural children to become "visible" as students. ${ }^{29}$ In establishing his argument, Symes draws on evidence largely absent from other histories of correspondence school summarized here: letters from children, photographs of the correspondence school staff, and school magazine articles. While his main focus rests on establishing how educational space was cultivated and reproduced in the context of correspondence schooling, evidence generated by correspondence school students is nonetheless front and center.

My analysis of the ECS family letters contributes to this historiography of correspondence schooling and rural schooling in two major ways: (1) it highlights the nature of rural education beyond the confines of material schools staffed by teachers, and (2) it focuses our attention on the attitudes toward, and experience of, rural schooling from the perspective of students and parents. In order to flesh out this history, it is important to note some contextual information regarding the development of schooling in Canada and the province. By the midnineteen century, compulsory elementary school attendance became a legal and civic requirement across Canada (except in Quebec), despite significant inequities and unevenness across provincial contexts. ${ }^{30}$ As the twentieth century loomed, government officials and educational professionals in Canada and beyond trumpeted compulsory public schooling as a key component of proper childhoods and

and Thomas Fleming and Tara Toutant, "A Modern Box of Magic': School Radio in British Columbia," Fournal of Distance Education 10, no. 1 (Spring 1995), 53-73.

${ }^{29}$ Colin Symes, "Remote control: a spatial history of correspondence schooling in New South Wales, Australia," International fournal of Inclusive Education 16, no. 5-6 (June 2012), 503-17.

${ }^{30}$ Gidney and Millar, How Schools Worked. 
engaged citizenship. ${ }^{31}$ After the First World War, and lingering for decades afterward, this meant cultivating schoolchildren's loyalty to Britain, British traditions, and the imperial vision of British colonization in Canada and elsewhere. ${ }^{32}$ In this context of white, middle-class hegemony in early twentieth century Canada and BC, and as histories of school exclusion make clear, public schooling was a right (or a good) never fully extended to every child equitably. ${ }^{33}$

BC entered the Canadian Confederation in 1871 with a nonsectarian school system. By 1872, the Public Schools Act supported education from the general revenues of the province and allowed the government to establish school districts and to appoint a Board of Education and a Superintendent. ${ }^{34}$ The Act was clear in its objective: "To give every child in the Province such knowledge as will fit him to become a useful and intelligent citizen in future years." ${ }^{35}$ The Public Schools Act of 1888 put more responsibility on local governments, shifting costs to districts and granting more power to local boards. These boards, confined exclusively to cities, were no longer elected; instead, the provincial government and city councils appointed board members (three and four members, including a chair, respectively).

${ }^{31}$ Ken Osborne, "'If I'm Going to Be a Cop, Why Do I Have to Learn Religion and History?': Schools, Citizenship, and the Teaching of Canadian History," in Settling and Unsettling Memories: Essays in Canadian Public History, ed. Nicole Neatby and Peter Hodgins (Toronto: University of Toronto Press, 2012), 135-87; see also David Tyack, "Ways of Seeing: An Essay on the History of Compulsory Schooling," Harvard Educational Review 46, no. 3 (Sept. 1976), 355-89; and Neil Sutherland, Children in English-Canadian Society: Framing the Twentieth Century Consensus (Toronto: University of Toronto, 1976).

${ }^{32}$ Timothy J. Stanley, "White Supremacy and the Rhetoric of Educational Indoctrination: A Canadian Case Study," in Children, Teachers and Schools in the History of British Columbia, ed. Mona Gleason and Jean Barman (Edmonton, AB: Brush Education, 2003), 113-32.

${ }^{33} \mathrm{See}$, for example, some recent work in the history of education in Canada that explores how those judged outside the boundaries of hegemonic social norms struggled for schooling equity. Alexandra L. Wood, "Challenging History: Public Education and Reluctance to Remember the Japanese Experience in British Columbia," Historical Studies in Education/Revue d'bistoire de l'éducation 25, no. 2 (Fall, 2013), 65-85; and Jason Ellis, "Inequalities of Children in Original Endowment': How Intelligence Testing Transformed Early Special Education in a North American City School System," History of Education Quarterly 53, no. 4 (Nov. 2013), $401-49$.

${ }^{34}$ Cuthbertson, A Highlight History of British Columbia Schools, 2. See also Jean Barman, "The Emergence of Educational Structures in Nineteenth Century British Columbia," in Gleason and Barman, Children, Teachers and Schools in the History of British Columbia, 13-37.

${ }^{35}$ Ibid. 
In small rural districts, however, this arrangement was deemed impractical. During the Great Depression of the 1930s, some school districts in $\mathrm{BC}$ were successfully "consolidated" into larger districts better able to service more students. Here, the government "assisted" schools with ten or more students by paying the teacher's salary. Local residents were responsible for the school building and any maintenance costs, such as repairs, fuel, and upkeep. ${ }^{36}$ In April 1946, as a result of the Cameron Report on Education in BC, an additional 650 districts were amalgamated as geographic, economic and/or political units into seventy-four municipal and rural districts. For many students who had attended the tiny "assisted" schools with their neighbors, this meant that, for the first time, they would take the school bus to a larger school in a larger community. ${ }^{37}$

As I argue in the sections to follow, many ECS families found the lack of governmental involvement in their rural and remote situation particularly unfair and objectionable. This history suggests strongly that state systems of education could be as much a product of the demands of families as they were a top-down strategy of government and governance. ECS families, spread across rural and remote areas of the province, did not qualify for the provision of assisted schools, nor was busing children to schools a workable option. It was particularly galling to many ECS parents that, while the government would neither build more schools nor provide the support families needed, it was seemingly relentless in its demand for rural people's continuous and often backbreaking labor and sacrifice.

\section{Leveraging Rurality: Remoteness, Isolation, and Calls for Governmental Support from Parents and Children}

Parents, particularly mothers, contacted the ECS by letter to request curricular materials for their children. Descriptions of isolation were a commonplace way for parents to ensure that they qualified for assistance and that the ECS teachers fully appreciated their struggles to educate their children. One such letter written to the ECS on January 3, 1923, by Mrs. E. M. Patterson from Shaw's Landing, Valdes Island, is an exemplary example. ${ }^{38}$ In her letter,

36"Rural and Assisted Schools," in The Homeroom: British Columbia's History of Education Web Site, https://www2.viu.ca/homeroom/rural/rurmain.htm.

${ }^{37}$ T. Fleming and B. Hutton, "School Boards, District Consolidation, and Educational Governance in British Columbia, 1872-1995," Canadian Fournal of Educational Administration and Policy, 10 (Jan. 14, 1997), https://www.umanitoba.ca/ publications/cjeap/articles/fleming10.htm.

${ }^{38}$ All proper names have been changed to provide anonymity to the letter writers. 
Mrs. Patterson justifies her request for correspondence school material by highlighting how the harsh physical environment presented significant challenges to her children's school attendance:

I have six children to whom school is an impossibility and my only neighbour on the island has a child also. We live on Valdes Island ... and we have no school, store, or post office. Our nearest school is over two miles away on Galiano Island but the intervening water in Portier Pass is very treacherous and unsafe. The tides flow through at from four to eight knots an hour and there are bad whirlpools in it. It is out of the question that the children could row there, and we have no motorboat, so I have been trying to teach them myself. ${ }^{39}$

Mrs. W. H. Baker, writing to the ECS branch in October 1924, highlighted similar challenges. The mother of two school-age children, a boy of seven years and a girl of eight, Mrs. Baker wrote that "I am a farmer's wife and live over 50 miles from town [Quesnel, BC] and 30 miles to the school which is in Baker Creek-it is too far in the winter to send them and during the summer, I am often alone on the ranch and have no way to get them to school." 40 Such descriptions of harsh landscapes and great distances to schools typified many letters in the ECS family files and hint at how rurality was leveraged as a way to draw attention to their concerns. In circumstances described as "remote," children depended on their parents to secure materials for their homeschooling. ${ }^{41}$ Likewise, homesteading parents depended on the labor contributions of their children. When sickness struck Lila Jenkins's family in April 1922, her schooling had to end-at least temporarily. "I am sorry to say," Lila wrote to the ECS, "there has been sickness in our family and I find I will not be able to go on with my lessons as I had hoped to. ... I will send all the fourth reader books back if so wished and thanking you for your kind attention to a very backward pupil." 42

For their part, young people contacted the ECS insisting on the deliverance of school materials or advising their teachers of their anxious desire to be successful and work ahead. Fifteen-year-old Helen Hayword, who resided in Chinook Cove, completed the paperwork

\footnotetext{
${ }^{39}$ Elementary Correspondence School, file 18, box 22, BCA.

${ }^{40}$ Ibid., file 35, box 22, BCA.

${ }^{41}$ More recently, scholars of Northern Canada in particular have questioned how the discourse of "remote" and "remoteness" is marshaled to support colonial attitudes toward the availability of land and its resources. See, for example, Roger Epp, "The Trouble with Remoteness," Northern Public Affairs (June 29, 2016), http://www.northernpublicaffairs.ca/index/the-trouble-with-remoteness/. I am indebted to Heather E. McGregor for this reference.

${ }^{42}$ Elementary Correspondence School, file 13, box 16, BCA.
} 
to enroll herself in the ECS in 1919. As was required in the application process, she informed her instructors that she had been in the Senior Fourth Reader when she last attended school and that she still had a number of books in her possession. ${ }^{43}$ Helen was clearly a self-motivated learner and eager to stay on par with other teenagers her age, as she informed the ECS that "when doing a little home studying I decided to begin at Part IV in the Spelling Book and at the beginning of all the other books and go right through with them." ${ }^{44}$ In June of 1921, twelve-year-old Edna McKay wrote that she would be "very much obliged to receive school books and lessons when you can send them." Edna told the administrators at the ECS that she had recently emigrated from England to Keithly Creek, BC. While at her former school, she reported, "we were doing long division," but in her new circumstances in a far-flung area of the province, she "had no school books. ... I live forty miles from the nearest school." ${ }^{5}$ In 1927, George Yeo in San Josef Bay, BC, contacted James Hargreaves, director of the ECS from 1919 to 1933, to report, "I think I will be able to finish Book II by the end of June." He ended his letter with a common plea: "Please send some more writing paper." 46

That Helen, Edna, and George took the initiative to pursue their schooling through correspondence speaks to the value they placed on getting an education and the power of successfully doing so. Like adult letter writers, these young people used the rhetoric of isolation to justify requests for material support and timely lesson planning. Having schoolwork to concentrate on represented an important way to mitigate the isolation they felt, far from the company of schoolmates, and to calm anxieties associated with falling behind in their lessons.

\section{Politicizing Rurality: Demands for Educational Equity and Governmental Attention}

Some mothers and children, seeking to continue their schooling, wrote to the ECS pointing out what they perceived to be an underestimation of the harsh conditions in which they lived. Mothers were not above

\footnotetext{
${ }^{43}$ Helen's books included Dominion School Geography, Canadian History, Symes and Wrong's English History, Milne's Progressive Third Arithmetic, Universal Spelling Book, Fourth Reader, Lady of the Lake, How to Be Healthy, Elementary Agriculture and Nature Study, B.C. Public School Grammar, and Elementary English Composition, Elementary Correspondence School, file 11, box 15, BCA.

${ }^{44}$ Ibid.

${ }^{45}$ Ibid., file 18, box 20, BCA.

${ }^{46}$ Ibid., file 9 , box 19 , BCA.
} 
chastising teachers, hinting at their refusal to comply with gendered notions of feminine reserve and passivity when it came to demanding assistance they felt fully entitled to. Ellen Harnett, writing in 1920 from Channel Cove, BC, some forty-one miles from the nearest town, lamented:

As a rule one does not try to be unreasonable. The department cannot understand the sometimes serious difficulties under which a good many settler in these scattered districts are working, trying to give their children something of an education. These things must be experienced to be realized even through we may feel entitled to it [educational resources], we are still grateful for any help we can get in that direction. ${ }^{47}$

In other letters, serious inadequacies with critical services, particularly postal service, preoccupied letter writers. ECS families relied entirely on regular and dependable mail service in order to send and receive the necessary lessons. Writing in April 1921 to Hargreaves, Mrs. Terence Hawkins communicated a sense of being overwhelmed not only by the family's isolation but also by the need to constantly strategize to ensure that resources and lessons were mailed and received in a timely manner. Her husband was the head keeper of the then newly built Triple Island Lighthouse, where the Hawkins family took up residence with their two small daughters, the lighthouse being located on a rocky outcrop of islands in Brown's Passage, on the western side of province. Mrs. Hawkins wrote:

We are terribly isolated here. The government tenders are our only means of communication and they do not call often more than once a month ... so books will mean a great deal ... could you not explain to the people in charge of that department and have a box [of books] sent up to Prince Rupert as soon as possible? If it could be managed that way it would save [a] two-month delay in reaching us as we would not receive an answer from you for one month and could not send the application for another month as the boat only deliver (sic) what it has for us then leaves. ${ }^{48}$

The urgency in Mrs. Hawkins's letter is palpable. Particularly striking is the acute desire to mitigate the family's physical and psychological isolation through books and lessons. The urgency she conveyed proved to be sadly prescient. In early 1923, two years after she wrote this letter, her husband contracted pneumonia and passed away. According to a history of the Triple Island Lighthouse, Mrs. Hawkins and her daughters, trapped on the tiny islet, "had no choice

\footnotetext{
${ }^{47}$ Ibid., file 12, box 15 , BCA.

${ }^{48}$ Ibid., file 20, box, 17, BCA.
} 
but to drag her husband's body up on the roof, where the freezing weather would preserve it, and then mind the light and fog alarm as duty dictated. Unable to get the attention of any passing vessels, Mrs. Hawkins tended the light for twenty days before the lighthouse tender finally called." 49

Under far less dramatic conditions, seventeen-year-old John C. Pentland also found himself coping with the consequences of living in isolated conditions, which he used to advocate for more attention from officials. He wrote to his ECS teachers in the spring of 1933 from his home in Wisteria, BC, warning that unless his teachers acted swiftly, lessons for him and his brother would not reach them and they would fall seriously behind in their studies:

Hank and I have only three more lessons after lesson 12, and Francois Lake is likely to be going out. When it goes out it stops the mail from crossing for weeks, so we are likely to be stuck with no lessons to do, so please send some more, for we don't get our mail every week. ${ }^{50}$

In some letters from parents, demands for increased attention from educational authorities extended to demands for appropriate pedagogical support. A number of letters to the ECS articulated parents' anxiety about the poor quality of their children's school progress. Many initial requests, for example, implicitly acknowledged that the right to receive a good education was part and parcel of their children's full participation in Canadian society, but that parents, particularly mothers, often felt unprepared to take up this task themselves. The fact that women were charged with the lion's share of domestic work, in conjunction with overseeing lessons, caused deep anxiety for many mothers. Gendered attitudes toward women's, and particularly mother's, diminished intellectual capabilities in relation to men (particularly husbands) may have played a role in the way mothers characterized their weaknesses in this regard. ${ }^{51} \mathrm{Mrs}$. W. H. Little, writing in 1924, remarked that while she felt inadequate to the job of guiding her children's lessons, "I would not like to see [her two children] grow up without any schooling." ${ }^{2}$ Mrs. A. B. Handman, writing from Cortez Island in November 1925 to explain why her children, Beverley and Adam, were "so long in sending their lessons in," explained, "I find it very difficult to give them much time as I have

\footnotetext{
49"Triple Islands, BC," Lighthouse Friends.com, http://www.lighthousefriends. com/light.asp? ID $=1436$.

${ }^{50}$ Elementary Correspondence School, file 33, box 23, BCA.

${ }^{51}$ Veronica Strong-Boag, The New Day Recalled: Lives of Girls and Women in English Canada 1919-1939 (Toronto: Copp, Clark, Pitman, 1988).

${ }^{52}$ Elementary Correspondence School, file 18, box 22, BCA.
} 
so many other duties to attend to.... I am anxious for them to get along with their work, but they cannot do their lessons alone." 53 Mrs. Patterson from Shaw's Landing similarly wrote in 1923, "I cannot teach them properly. Every moment of my time is overworked and it breaks my heart to see them growing up in ignorance." ${ }^{54}$ Like Mrs. Patterson, Mrs. Connor Regan from Jackson Bay, BC, wrote in 1925, "I will take on the fourth year work when you send it although I feel incompetent. ... But will do the best I can in dictating at all times." ${ }^{55}$

Despite such expressions of their own inadequacies and lack of professional training, these mothers were nonetheless persistent in using the sacrifices they made to support the economic demands of the province to petition for their children's right to be educated properly as Canadian citizens. Eric Alder, writing to Hargreaves in 1921 from Cascade, BC, plainly blamed the failing of the ECS system rather than personal inadequacies for difficulties with lessons. In his letter, rurality was clearly marshaled as a politicized rhetorical tool to demand better treatment:

\begin{abstract}
Your system is too complicated for the average person. ... I have since been making inquiries - I think there must be schools put where they are doing the least good for there is no change in the rural districts in the last 20 years and in fact we at one time could get a teacher with 8 pupils - now we need 10 - that is one reason so many leave these parts never to come back again. ${ }^{56}$
\end{abstract}

Other parents were keen to receive educational materials from the ECS, but saw no benefit in having to register their children with the department. For example, Mrs. S. G. Walter from 100 Mile House, BC, contacted Hargreaves in the early summer 1928 to express her anger at his refusal to send her schooling materials without registration in the ECS. Mrs. Walter argued that the family paid school taxes that year but could not send their children to the nearby school at Lac La Hache, since distance and the harsh terrain prevented them from regular attendance. The family also refused to board their young children out in homes closer to the school, citing the cost of doing so. She wrote:

All we are asking for is one reader and a pack of drawing paper. I may say I would not take the trouble to send for it if it were not needed. What do you suppose we are doing with the other material? Why, we used it of

\footnotetext{
${ }^{53}$ Ibid., file 12, box 22, BCA.

${ }^{54}$ Ibid., file 18, box 22, BCA.

${ }^{55}$ Ibid., file 51, box 23, BCA.

${ }^{56}$ Ibid., file 6, box 16, BCA.
} 
course. ... Seeing that our taxes for school to educate other children are $\$ 15.00$ which we consider out of all reason (our own children receiving no benefit at all from it). Mr. Walter wishes me to say he will be much obliged to receive the necessary material as soon as possible so that our children may lose no time. If not, he will have to take the matter further. ${ }^{57}$

Mrs. Walter was clearly willing to defend what she understood as her right to access educational materials. Having paid taxes without reaping the benefits made her arguments all the more forceful. Clearly, however, she was not above including a thinly veiled threat regarding legal action against the ECS. By evoking the reference to her husband's involvement in the matter, she capitalized on gendered notions of the prerogative of male heads of households to protect their interests.

\section{Rurality in Sharp Relief: The Great Depression and Rural Disadvantage}

By the 1930s, the serious economic hardship associated with the Great Depression befell many families in Canada. Regions such as BC that depended on resource-based economic growth were particularly hard hit. ${ }^{58}$ The tensions associated with homeschooling children that had always characterized the ECS were exacerbated in this period. Rural families were forced to make ever more difficult decisions, and they did not hesitate to complain about this burden in their letters. Alex J. Denton from Surge Narrows, BC, contacted the ECS in 1930 to ask whether withdrawal from the lessons for his young daughter was the best option given the family's inability to marshal funds:

We received this letter from you some time ago but on account of unemployment and hard times we have been unable to get all these books. With no outlook for any work at present, I don't see how I can get the other two [books]. What do you suggest? Should Charlotte drop some of her subjects from her lessons? ${ }^{59}$

The Denton family lived on a small island three and a half miles from the nearest school. Their young daughter had to be transported the final mile and a half across a channel and, according to her father, "The girl has no adequate winter clothing to travel by boat or adequate shoes." 60 Correspondence school was the best option for educating

${ }^{57}$ Ibid., file 14, box 25, BCA.

${ }^{58}$ Jean Barman, The West Beyond the West: A History of British Columbia, 3rd ed. (Toronto: University of Toronto Press, 2007), see especially Chapter 11, "The Best and Worst of Times, 1929-1945," 252-86.

${ }^{59}$ Elementary Correspondence School, file 7, box 24, BCA.

${ }^{60}$ Ibid. 
Charlotte, but the costs of books, however minimal, was a significant barrier that rural families faced. Similarly, Mrs. R. D. Michelson wrote to the ECS in the spring of 1934 from her home in Tatla Lake asking for some support for teaching her children:

Lacking a blackboard, I find it difficult to drill my children, as much as should be done, in Arithmetic, etc. I have tried various articles as substitute for blackboard, among others the tops of black gum-boots tacked side by side on the wall. But it is all makeshift and unsatisfactory. The cost of food, etc., is high in this part of the country, and it seems our money never goes quite far enough to pay for a blackboard. So, feeling rather desperate about giving these youngsters an education, I have finally gathered enough courage to ask you for help. Could I, somehow or other obtain one through your Department? ${ }^{31}$

Lack of school supplies was a common complaint in the ECS letters and also hampered the progress of Mrs. Timothy Beecher's son. Mrs. Beecher wrote the ECS in the fall of 1933 from their homestead in Arras, BC, to ask the teachers to "have a little patience with Francis ... he has not had any schooling for one and half years ... being forty years since I left school, I do not always grasp the lessons as I ought and it makes it more difficult for him."

I am sorry to say I have not been able to purchase the crayons, paints or the Dominion Language Series, Book 1. We have only 11 dollars per month to live on and there are five of us to keep out of that: Mr. Beecher, myself, 3 sons, 1 aged 26,1 aged 16, and Francis aged 10 years and I'll assure you we have to count every cent before we spend it. ${ }^{62}$

In 1935, Mrs. D. Piper from Giscome, BC, wrote to Isobel Bescoby, director of the ECS between 1934 and 1937, to explain the lack of progress in her children's lessons. Like other families, the Pipers found it difficult to cope with the costs associated with correspondence education. Her husband's ill health significantly exacerbated these difficulties:

We applied for relief and received a small monthly allowance just enough for groceries and, by scrimping on them, a few of the most necessary clothing. Mr. Piper asked to be allowed enough to pay postage and school supplies but he was refused ... the children have to help me get the garden stuff in and cut a supply of wood before the deep snow or real cold weather sets in. I do not think children can do good lessons when they are tired from outside work. ${ }^{63}$

\footnotetext{
${ }^{61}$ Ibid., file 2, box 6, BCA.

${ }^{62}$ Ibid.

${ }^{63}$ Ibid., file 51, box 24, BCA.
} 
By 1937, the Piper children had dropped out, re-enrolling in the ECS as resources allowed. When the children again failed to hand in lessons, Mrs. Piper wrote to Bescoby to once more explain the family situation. Her husband's health had further deteriorated by that time. "The children" she wrote, "do most of the work." While Mr. Piper took up limited employment by plowing neighbors' roads in the winter, the children had to accompany him, as Mrs. Piper explained:

I can't have him alone on the road so one or two of the children have had to be along to help him to remove drifts and be with him if anything happened to him. The children are spending every minute of extra time on their lessons. We also have stock to water and feed and wood to be cut. ${ }^{64}$

In the spring of 1938, Mrs. Piper notified the ECS that her eldest daughter, Emma, then fifteen years old, would not be continuing with her lessons. According to her, Emma found them too hard and too confusing and she was desperately needed to do work around the house. Mrs. Piper wondered whether some form of examination could be given to Emma so that she could pass out of elementary school based on the work she had previously done. "She is not intending to go to high school anyway," wrote Mrs. Piper. ${ }^{65}$ Only two days earlier, Emma had written directly to her teacher at the ECS asking for more time to complete her Grade 8 work and requesting that her subjects be cut back in order to do so. "I have read several advertisements lately of a place I can write and learn to be a nurse... I have always wanted to be a nurse," Emma optimistically wrote. ${ }^{66}$ It is clear that Mrs. Piper's letter communicated a much more circumscribed vision of the future than Emma held for herself. Given the lack of social support the Pipers received from the province, the ongoing costs associated with schooling her children, and the medical challenges facing the family breadwinner, it is not surprising that the ECS lessons were not a priority for her. Emma, nevertheless, seemed to hold out hope that her future might offer more opportunities if she persevered.

The willingness of rural working-class families to politicize their rural condition in letters to ECS officials speaks to their agency in the face of precarious financial situations. While desperation, and even humiliation, comes through in a number of letters parents wroteparticularly those who could not afford schooling supplies or whose children worked at the expense of schooling-others pointed to governmental neglect as the real culprit. In 1938, Mrs. Layton from

${ }^{64}$ Ibid.
${ }^{65}$ Ibid.
${ }^{66}$ Ibid. 
Cowichan Lake communicated multiple layers of difficulty with schooling her children at home through the ECS. The first layer involved difficulties with the curriculum and a home unsuitable for schoolwork:

The Inspector of School was out to look the school situation over and he could, at a glance, see the big handicap the children are trying to do their lessons under. For example, Harry was trying to puzzle out Lesson 13 of Mathematics (the lesson which came back to him to be repeated about 6 times). He showed Harry how to do the work but the children were working in a very badly lit room and all about one small table. The rain was just pouring, and you know how dark any room gets in that kind of weather. We use coal oil lamps, and that helps a little bit but really does more harm than good. ${ }^{67}$

While the school inspector was clearly aware of the limitations of schooling by correspondence, he seemed unable, or disinclined, to do much about it. Indeed, given the reliance on parental (maternal) oversight of lessons in the ECS approach, many families found themselves at a distinct disadvantage. This was particularly true given the second layer of difficulties the Layton family faced: the ill health of Mrs. Layton herself. As a person with a "weak chest," Mrs. Layton was often "in bed and I help the children by having them come into the bedroom and to solve a problem ... I often have to leave the children to do their own work and trust to their own ingenuity to do it correctly." 68

Still other parents were far more defiant in the face of the conditions they found themselves in vis-à-vis their children's correspondence schooling. Writing in 1934 to Bescoby from his farm in Mapes, BC, Frank Ellard did not make any excuses for his two sons' lack of progress with their lessons:

The children of rural Canada are the caretakers of the nations' food supply and compared to the city child sacrifice their education in order that urban populations may eat without any regard to the cost of production ... your kindly offer of additional assistance is not needed, for the trouble is purely economic. ... We live a Robinson Crusoe existence. Up to the present, taxation demands $\$ 50.00$ per annum cash (seven times my total cash income) ... in consequence of the above, I am on relief with $90 \%$ of this District and have been compelled to put in my work in this connection 28 miles from home ... work at home falls upon these two boys during my long absences to the serious detriment of their schooling. ${ }^{69}$

\footnotetext{
${ }^{67}$ Ibid., file 44, box 25, BCA.

${ }^{68}$ Ibid.

${ }^{69}$ Ibid., file 3, box 26, BCA.
} 
Parents like Ellard were clearly not willing to blame their difficult circumstances on personal inadequacies. Citing instead the absence of a state infrastructure that hampered educational equity in rural locations, Ellard offered an indictment of what he perceived as the triumph of governmental greed and neglect over the advancement of rural children.

\section{Conclusions: Rurality and the Promise of Schooling}

By 1948, H. McMaster, Inspector of Schools in the rural district of Kamloops, BC, contacted the new director of the ECS, Anna Miller (1937 to 1950), to ask for advice on how to deal with simmering unrest among parents in his district: "Since the formation of larger school districts [through postwar consolidation] parents in communities where no schools exist are objecting to the time and work which they state is required of them in assisting their children who are taking correspondence courses.... They state that since they are paying the same taxes as parents residing in communities where schools are open, that they should be reimbursed for the work they are doing." 70 McMaster asked Miller how to respond to questions regarding how much time parents were expected to spend on supervising their children's work. Miller was sympathetic to the parents, acknowledging that "home instructors," primarily mothers, she conceded, were often required full time for younger students, with this easing up only very gradually as children got older. ${ }^{71}$ This important acknowledgment of the unrealistic expectations placed on settler parents pursuing education for their children foreshadowed the end of the ECS over the next decades. Fewer students used the service as the population of the province grew, more schools opened in underserviced districts, and infrastructure projects resulted in improved ground and water transportation. Better communication resources, including the radio, television, and telephone, were adapted to serve educational ends. ${ }^{72}$ Less a compulsory service that provided elementary schooling and more an optional offering that supplemented what children (and adults) learned in brick-and-mortar schools, by the end of the 1970s, the ECS had dissolved into a "distance education" service. ${ }^{73}$

From the vantage point of the settler parents and children explored in this paper, such improvements were a long way off. The

\footnotetext{
${ }^{70}$ Ibid., file 2, box 2, BCA.

${ }^{71}$ Ibid.

${ }^{72}$ Fleming and Toutant, "A M Modern Box of Magic."

73 "Correspondence Education", The Homeroom, https://www2.viu.ca/homeroom/content/topics/programs/corresp.htm.
} 
incompatibility between social pressure to enroll their children in the ECS and the need to make economic ends meet under trying rural conditions was at the crux of difficult decision-making reported in many family letters. The promise of future benefits that formal schooling might have held was ultimately no match for the more basic need of family survival in the here and now. Through the letters we experience firsthand the trepidation of many parents, particularly mothers, as they embarked on educating their children in less-than-ideal conditions. We also hear, loud and clear, the discontentment that these families felt with a provincial government characterized as shirking its responsibility to provide a meaningful educational infrastructure.

In this article, I've argued that the family letters in the ECS collection provide a glimpse into the attitudes toward, and experience of, getting an education on the part of the rural working class. In their letters, rurality, as both a material reality and as politicized rhetoric, is leveraged as a strategy to argue for more equitable treatment. The particularities of living in rural locations intertwined with racialized, classed, and gendered social relations to shape the experiences of settler parents and children. Both mothers and fathers lobbied for their children to have access to schooling in ways that did not set them back from their working- and middle-class peers in more populated areas. Some letter writers commented directly on their disadvantages in this regard and communicated a sense that ECS teachers and officials did not understand, or were disdainful toward, their rural working-class reality. That children's labor was required on many homesteads was a common complaint from parents in response to accusations from ECS teachers of children's tardiness or poorly done work. In the absence of meaningful assistance, moving to more populated areas was touted as a real, if unfortunate, choice for settlers concerned about schooling. These were compromises, however, that few urban middle- or working-class families had to make, especially by the middling decades of the twentieth century in Canada. Many rural working-class families, however, still had to make this difficult choice - to make a living or to attend to children's formal elementary schooling - and the latter often came second out of necessity.

The ECS letters demonstrate that the settler families in rural and remote locations in the province understood the worth of quality schooling and demanded more provincial governmental support in its pursuit. In this way, families articulated clear expectations regarding what they believed to be appropriate levels of state involvement concerning schooling and education. Dominated by the demands of an agricultural and resource-based economy, settler families looked to their provincial government to help mitigate the hardships associated with forging a life far from any town or city. Expectations about 
support from the provincial government included adequate numbers of brick-and-mortar schools, subsidies for hiring private tutors or professional teachers, and the basic provision of services and supplies, such as postal delivery, postage, maps, additional books, paper, pencils, and pens. Recalling the point Collins and Coleman made earlier in the article regarding schooling having a place in the imagination of a community, ECS families envisioned treatment from their government that was on par with their urban counterparts and that acknowledged their contributions to the economic growth of their province.

Parents, particularly mothers who wrote the vast majority of letters to the ECS, nevertheless emerge as more than willing to exercise their own agency. They marshaled their rural condition to improve their family circumstances, decrying the lack of support afforded them. Similarly, children and young people used the isolation associated with their rural condition to keep up the pressure on their ECS teachers for attention and supplies. For all the trials and tribulations endured by the ECS families, however, many parents continued to hold up schooling as the best hope for social progress and their children's stake in it. As Frank Ellard suggested in his letter to James Hargreaves in 1929, only through a proper education would the future truly be secure. He understood that the fair provision of education was critical so that "the children could come to know themselves and the human being in a manner surpassing the adults around them." ${ }^{74}$

\footnotetext{
${ }^{74}$ Elementary Correspondence, file 3, box 26, BCA.
} 